\title{
Supplementing Intensively Grazed Late-Gestation and Early-Lactation Dairy Cattle with Chromium
}

\author{
M. A. Bryan, ${ }^{1}$ M. T. Socha, ${ }^{2}$ and D. J. Tomlinson ${ }^{2}$ \\ ${ }^{1}$ Central Southland Veterinary Services Limited, Winton, New Zealand \\ ${ }^{2}$ Zinpro Corporation, Eden Prairie, MN 55344
}

\begin{abstract}
Two hundred thirty-two primiparous and multiparous cows were assigned to a study to determine the effect of supplementing 0 or $6.25 \mathrm{mg} / \mathrm{d}$ of $\mathrm{Cr}$ from $\mathrm{Cr}$ Met on lactation and reproductive performance. Cows received treatments from 6 wk precalving through 21 wk postpartum. Precalving, treatments were incorporated into a pelleted grain mixture and group-fed. Postcalving, cows received treatments via an individual oral drench once a day after the a.m. milking. Grazed herbage was the primary diet constituent for lactating cattle. Blood was collected from a predetermined group of cows before and immediately after calving. On 4 occasions during the treatment period, milk yield was recorded and samples collected for determination of composition. Chromium supplementation had no effect on yield of milk and milk components and milk composition. Chromium supplementation decreased serum nonesterified fatty acids (NEFA) concentration ( $0.60 \mathrm{vs.}$ $0.68 \mathrm{mmol} / \mathrm{L}$ ), with chromium supplementation having the greatest impact on serum NEFA concentrations at 1 wk prepartum. Greater percentages of cows supplemented with $\mathrm{Cr}$ were observed to be anestrus by dairy personnel (45.5 vs. $32.0 \%$ ). However, Cr supplementation tended to increase the percentage of cows pregnant in the first $28 \mathrm{~d}$ of the mating season (50.0 vs. 39.2\%). Results indicate that Cr Met supplementation of intensely grazed, late-gestation and early-lactation dairy cattle decreased serum NEFA concentrations and tended to increase pregnancy rates in the first $28 \mathrm{~d}$ of the mating season.
\end{abstract}

(Key words: dairy cattle, chromium, intensive grazing)

Abbreviation key: ECM = energy-corrected milk.

\section{INTRODUCTION}

Chromium is generally accepted as an essential nutrient that potentiates insulin action and thus influ-

Received February 27, 2004.

Accepted August 12, 2004.

Corresponding author: M. T. Socha; e-mail: msocha@zinpro.com. ences carbohydrate, lipid, and protein metabolism (Mertz, 1993). Chromium also aids in the conversion of thyroxine to triiodothyronine, increasing the metabolic rate (Burton, 1995).

Chromium supplementation of late-gestation and early-lactation dairy cattle may be particularly beneficial. In rats, the fetus accumulates $\mathrm{Cr}$, especially in the last trimester, depleting $\mathrm{Cr}$ stores (Anderson, 1987). Also, stress, such as the stress of late gestation and early lactation, increases urinary excretion of $\mathrm{Cr}$ in rats (Borel et al., 1984; Anderson et al., 1988), further depleting Cr stores.

Chromium supplementation may mediate immune suppression often observed in stressed animals. Newly arrived beef cattle supplemented with $\mathrm{Cr}$ had improved humoral immunity as indicated by increased vaccination titers (Burton et al., 1994), and increased serum IgM, IgG (Almeida and Barajas, 2001; 2002), and total immunoglobulin concentrations (Chang and Mowat, 1992; Moonsie-Shageer and Mowat, 1993). Cell-mediated immunity of late-gestation and early-lactation cows also improved in response to $\mathrm{Cr}$ as shown by increased lymphocyte blastogenesis (Burton et al., 1993) and increased production of interleukin-2, interferon$\gamma$, and tumor necrosis factor- $\alpha$ (Burton et al., 1996).

Another benefit of chromium supplementation to the periparturient cow is reduced blood NEFA concentrations (Yang et al., 1996; DePew et al., 1998; Hayirli et al., 2001). Elevated blood NEFA concentrations have been associated with increased risk of periparturient metabolic disorders (Cameron et al., 1998; Drackley, 1999). Reduced blood NEFA concentrations can be partially attributed to increased DMI, commonly observed in response to postpartum Cr supplementation (Hayirli et al. 2001; Smith, 2004). In conjunction with increased DMI, milk yield has increased in response to $\mathrm{Cr}$ supplementation (Yang et al., 1996; Hayirli et al., 2001; Smith, 2004).

Improving immune function and reducing tissue mobilization may improve fertility of cattle. Research has shown that the incidence of retained placenta is higher in cows with impaired immune function (Gunnink 1984; Kimura et al., 2002), and retained placentas reduce fertility of cattle (Campbell et al., 1999; McDougall, 
2001). Also, reducing blood NEFA has improved fertility of dairy cattle (Westwood et al., 2002). To date, limited research has examined the effect of $\mathrm{Cr}$ on fertility of cattle.

The $\mathrm{Cr}$ studies summarized above were conducted with dairy cattle fed diets consisting of cereal grains, oilseed meals, and preserved forages. Research has not examined the effect of supplementing intensively grazed dairy cattle with chromium. In particular, response of intensively grazed dairy cattle in New Zealand may differ, as their diets consist primarily of grazed herbage, and some New Zealand dairy cattle, particularly high-producing cows, may be limited in their ability to consume more DM. The objective of this study was to examine the effect of supplementing intensively grazed New Zealand dairy cattle with $\mathrm{Cr}$ from Cr Met, from approximately 6 wk precalving through $21 \mathrm{wk}$ postcalving, on lactation and reproductive performance, as well as on blood and liver composition.

\section{MATERIALS AND METHODS}

\section{Experimental Animals and Diets}

All procedures related to animal care were conducted with the approval of the Animal Ethics Committee of the Massey University Animal Health Services Center (Palmerston North, New Zealand). Two hundred thirtytwo cows (average BW, $514 \mathrm{~kg}$ ) from a commercial dairy were assigned to a study to determine the effect of feeding 0 or $6.25 \mathrm{mg} / \mathrm{d}$ of Cr from Cr-L-Met (MiCroPlex, Zinpro Corporation, Eden Prairie, MN) on lactation and reproductive performance, as well as blood and liver parameters. One hundred twenty-two cows were assigned to the control diet (24 primiparous cows and 98 multiparous cows), and 110 cows were assigned to the Cr-supplemented diet (19 primiparous cows and 91 multiparous cows). Cows received treatments from approximately $6 \mathrm{wk}$ before calving through $21 \mathrm{wk}$ postpartum. Treatment groups were matched according to age, expected calving date, lactation worth, breeding worth, and previous lactation dry cow therapy, and then randomly assigned to treatments.

During the last 6 wk of gestation, both treatment and control cows received $1 \mathrm{~kg}$ of a pelleted grain supplement. The ingredient composition of the grain supplement fed to both groups of cows was similar except that the $\mathrm{Cr}$ grain supplement contained $6.25 \mathrm{mg} \mathrm{Cr} / \mathrm{kg}$ from Cr Met. The pelleted grain supplement was delivered to cows by dispensing it on the ground under the break wire (Winton Seed Precalving Close-Up Pellet, Winton Stock Feed Ltd., Winton, New Zealand). The 2 groups of cows were kept in the same paddock during this time but were separated by an electric fence.
In the early dry period, cows were allotted daily (DM basis) approximately $8 \mathrm{~kg}$ of turnips (herbage and tuber), $4 \mathrm{~kg}$ of grass-legume silage (mixture of midmaturity perennial ryegrass and white clover baled and then ensiled in plastic wrapping), and $1 \mathrm{~kg}$ of barley straw in addition to $1 \mathrm{~kg}$ of the grain supplement. The last 2 to $3 \mathrm{wk}$ before calving, cows were offered daily (DM basis) approximately 2 to $3 \mathrm{~kg}$ of wheat silage, $6 \mathrm{~kg}$ of pasture (70\% perennial ryegrass and $30 \%$ white clover $\mathrm{mix}$ ), and $4 \mathrm{~kg}$ of grass-legume silage in addition to 1 $\mathrm{kg}$ of the grain supplement. Allotment of turnips and pasture was controlled by the amount of area cows were allowed to graze. Silage, straw, and grain were delivered to cows under the break wire.

Samples of feedstuffs offered during the prefresh period were sampled once and analyzed for nutrient content (R. J. Hills Laboratories, Hamilton, New Zealand). Feedstuffs offered during the postpartum period were sampled monthly and analyzed for nutrient content ( $R$. J. Hills Laboratories). In both the pre- and postpartum period, mineral content of feedstuffs was determined using atomic absorption (R. J. Hills Laboratories). Nutrient content of feedstuffs and grain supplements are given in Table 1.

Postcalving, grain supplementation was discontinued and treatments were individually delivered to cows via an oral drench once a day after the a.m. milking. The liquid drench was diluted with tap water so that a $20 \mathrm{~mL}$ dose delivered $6.25 \mathrm{mg}$ of $\mathrm{Cr}$ from $\mathrm{Cr}$ Met. Several measures were taken to keep drenching errors to a minimum. First, one person was dedicated at each a.m. milking solely for drenching. Second, colored ear tags were used to identify the 2 groups. Third, cows were drenched once daily. Fourth, cow numbers were recorded once weekly to verify cows that were to be drenched were not being missed because of a lost ear tag. Fifth, only cows receiving the $\mathrm{Cr}$ treatment were drenched. As cows had been routinely drenched in the past, drenching was accepted by the cows with minimum discomfort and appeared to have minimal effect on animal behavior and performance.

Control and treatment cows were managed as one group postpartum. Each day, control and treatment cows grazed in the same paddock, walked the same track between the milking parlor and paddock, and were milked during the same time period by the same dairy personnel. Cows were offered daily (DM basis) approximately $4 \mathrm{~kg}$ of wheat silage and ad libitum pasture. In late spring, cows were also given 0.5 to $1 \mathrm{~kg}$ of barley straw. No grain supplements were offered postcalving. Precalving and postcalving, treatment and control cows received daily $360 \mathrm{mg}$ of $\mathrm{Zn}, 200 \mathrm{mg}$ of $\mathrm{Mn}, 125 \mathrm{mg}$ of $\mathrm{Cu}$, and $12 \mathrm{mg}$ of Co from complexed trace minerals (Availa4, Zinpro Corporation) and 300 
Table 1. Chemical composition of feeds fed during the study.

\begin{tabular}{lcccccc}
\hline Item, & $\begin{array}{l}\text { Pasture, } \\
\text { intensively } \\
\text { managed }^{1}\end{array}$ & $\begin{array}{l}\text { Turnips, } \\
\text { tuber, and } \\
\text { herbage }\end{array}$ & $\begin{array}{l}\text { Chromium } \\
\text { grain mix }^{2}\end{array}$ & $\begin{array}{l}\text { Control } \\
\text { grain mix }^{2}\end{array}$ & $\begin{array}{l}\text { Mixed } \\
\text { grass- } \\
\text { legume } \\
\text { silage }^{3}\end{array}$ & $\begin{array}{l}\text { Wheat } \\
\text { silage, } \\
\text { early } \\
\text { head }\end{array}$ \\
\hline $\mathrm{CP}, \%$ & 24.7 & 14.4 & 12.1 & 11.7 & 20.3 & 10.4 \\
$\mathrm{ADF}, \%$ & 22.3 & 13.3 & 10.0 & 8.2 & 25.1 & 32.8 \\
$\mathrm{Ca}, \%$ & 1.86 & 0.79 & 1.49 & 1.16 & 1.51 & 0.44 \\
$\mathrm{P}, \%$ & 0.41 & 0.32 & 0.42 & 0.44 & 0.36 & 0.22 \\
$\mathrm{Mg}, \%$ & 0.36 & 0.17 & 0.81 & 0.63 & 0.32 & 0.14 \\
$\mathrm{~S}, \%$ & 0.18 & 0.51 & 0.19 & 0.19 & 0.20 & 0.15 \\
$\mathrm{Fe}, \mathrm{mg} / \mathrm{kg}$ & 186 & 160 & 443 & 371 & 168 & 276 \\
$\mathrm{Zn}, \mathrm{mg} / \mathrm{kg}$ & 19 & 23 & 498 & 539 & 31 & 20 \\
$\mathrm{Mn}, \mathrm{mg} / \mathrm{kg}$ & 36 & 18 & 297 & 371 & 9 & 6 \\
$\mathrm{Cu}, \mathrm{mg} / \mathrm{kg}$ & 11 & 3 & 145 & 181 & 1.0 & 2.2 \\
$\mathrm{Cr}, \mathrm{mg} / \mathrm{kg}$ & 0.8 & 0.7 & 5.8 & 1.1 & &
\end{tabular}

${ }^{1}$ Grass-legume mixture, $70 \%$ perennial ryegrass and $30 \%$ white clover.

${ }^{2} \mathrm{~A}$ mixture of barley and wheat (Winton Seed Precalving Close-Up Pellet, Winton Seed Co., Winton, New Zealand).

${ }^{3}$ Baled silage, mid maturity, consisting of $70 \%$ perennial ryegrass and $30 \%$ white clover.

mg of monensin (Rumensin, Elanco Animal Health, Indianapolis, IN). The allotted minerals and monensin were delivered to cows by metering the products into the drinking water using a nonelectrical proportional liquid dispenser (Dosatron, Dosatron International, Tresses, France). During the spring grazing season, cows also received bloat oil for the prevention of bloat.

With the exception of the herd owner and the dairy manager, all individuals involved in the trial were blinded to treatment assignments, minimizing any potential bias of trial evaluators. Only after collection and analyses of trial data was completed were trial evaluators informed of treatment assignments by the herd owner and the dairy manager.

\section{Blood and Liver Sampling}

Twenty cows from each treatment group were randomly selected for blood and liver sampling. Blood samples were collected at dry off, 1 wk before expected calving and 1,2, and 4 wk postcalving. Blood samples were obtained by venipuncture of the coccygeal vein during or immediately after the p.m. milking. Blood was collected into a $10-\mathrm{mL}$ evacuated tube containing no anticoagulant and a 5-mL evacuated tube containing sodium heparin (Vacutainer, Becton Dickinson, Rutherford, NJ). Tubes containing anticoagulant were chilled (placed in insulated packs with ice during transit to the clinic, and refrigerated at the clinic until shipped later that day) and remained chilled (shipped in insulated packs with ice) during overnight transport to the laboratory (Alpha Scientific, Hamilton, New Zealand). At the laboratory, samples were placed in an ice bath until centrifuged at $3500 \times g$ for $20 \mathrm{~min}$ at $5^{\circ} \mathrm{C}$. An aliquot of plasma was removed and stored at $4^{\circ} \mathrm{C}$ until further analysis (within $24 \mathrm{~h}$ ). Blood in tubes containing no additive was allowed to clot at ambient temperature $\left(15\right.$ to $21^{\circ} \mathrm{C}$ ), before being transported overnight to the laboratory (Alpha Scientific). At the laboratory, they were centrifuged $(3500 \times g$ for $10 \mathrm{~min})$, and the serum stored at $4^{\circ} \mathrm{C}$ until further analysis (within $24 \mathrm{~h}$ ). Samples were analyzed for plasma glucose concentrations and serum NEFA, insulin, and BHBA concentrations.

Liver samples were collected from the same cows at dry off, $1 \mathrm{wk}$ before expected calving, and $4 \mathrm{wk}$ postcalving. Biopsies were performed with the cow standing in a cattle chute with its head secured in a metal yoke. A $5 \times 5 \mathrm{~cm}$ square in the 10 th or 11 th intercostal space, one hand width below the transverse processes on the right flank, was shaved, disinfected with hibitane and iodine, and anesthetized with $10 \mathrm{~mL}$ of a $2 \%$ lidocaine solution. A $0.5-\mathrm{cm}$ slit in the skin was made with a scalpel. Next, a liver biopsy trocar (length $20 \mathrm{~cm}$, i.d. $4 \mathrm{~mm}$ ) was inserted through the slit in the cranioventral direction. After puncturing the liver capsule, the inner portion of the trocar was removed, and a 1.5- to 2.5$\mathrm{cm}$ liver sample was taken. Following the biopsy, skin incisions were dusted with a broad-spectrum antibiotic powder (Aureomycin, Fort Lee, NJ) to help prevent sepsis. Samples were placed in sterile tubes, chilled (shipped in insulated packs with ice), and transported overnight to the laboratory by courier. Samples were submitted (Alpha Scientific) for determination of $\mathrm{Zn}$, $\mathrm{Cu}, \mathrm{Mn}$, and vitamin $\mathrm{B}_{12}$ concentration.

\section{Production and Reproduction Data}

Cows were milked twice daily. At 4 time points, at approximately 6 -wk intervals, milk yield was deter- 
mined and milk samples collected for determination of milk composition (Livestock Improvement Corp., Hamilton, New Zealand). Based upon measured milk production, milk composition, and DIM from known calving dates, total milk and milk solid production was calculated (Livestock Improvement Corp.). However, for statistical analysis of energy-corrected milk (ECM, $3.5 \%$ fat and $3.2 \%$ protein) and 3.5\% FCM, actual data from the 4 milk tests performed by Livestock Improvement Corporation were used rather than estimating daily milk production using milk production totals and DIM.

Reproductive management was done in accordance with standard operating procedures of the dairy. At 7 $\mathrm{d}$ before planned start of mating, cows that were not observed in estrus by dairy personnel following $3 \mathrm{wk}$ of estrus detection were presented to the veterinarian for examination. Upon rectal palpation, cows that were deemed anestrus by dairy personnel, but had appropriate ovarian luteal tissue present were given $2 \mathrm{~mL}$ of prostaglandin (Estrumate, Schering Plough Animal Health, Auckland, New Zealand). Cows with no ovarian activity were given a progesterone-releasing vaginal implant (Cue-Mate, Pfizer Animal Health, Auckland, New Zealand). Cows with adhesions or scarring of the reproductive tract were not treated. Any cow diagnosed with endometritis by rectal or vaginal palpation was given an intrauterine infusion of $500 \mathrm{mg}$ of cephapirin (Metricure, Intervet, New Zealand).

After $6 \mathrm{~d}$, the progesterone-releasing vaginal implant was removed. The following day, cows were given 1 $\mathrm{mg}$ of estradiol benzoate (Cidirol Bomac Laboratories, Manuka City, Auckland, New Zealand) intramuscularly.

All cows were bred (by AI) upon detected estrus for the first $7 \mathrm{wk}$ of the mating season. Cows deemed in estrus at the a.m. milking were sorted from the herd and bred following the a.m. milking. Cows deemed in estrus at the p.m. milking were sorted from the herd and bred following the p.m. milking. After the first 7 wk of the mating season, AI breeding was discontinued, and beef bulls were introduced to the herd. Beef bulls remained with the herd for $6 \mathrm{wk}$. Following removal of the beef bulls from the herd, cows were checked for pregnancy using rectal ultrasound to assess pregnancy rates in the first 28 and $44 \mathrm{~d}$ of the breeding period. Cows were checked again 6 wk later using rectal ultrasound to determine pregnancy rates in the first $60 \mathrm{~d}$ of the breeding period and to confirm final pregnancy rates.

\section{Statistical Analyses}

Statistical analyses were performed on the 3 sets of outcome data: blood and liver data, milk production data, and reproductive data. Statistical analyses were performed using SPSS (SPSS Inc, Chicago, IL) and NCSS (NCSS, Kaysville, UT). Power analyses were performed using PASS (NCSS), and Power and Precision (Biostat, Englewood, NJ).

Analysis of blood and liver data were performed using 2 -tailed $t$-tests and ANOVA of SPSS. Effects included in analysis of the blood data were sample collected before treatment administration (covariate), time, treatment, and time $\times$ treatment interaction with the individual cow as the random effect and treatment group as a fixed effect. Effects included in analysis of the liver data were sample collected before treatment administration (covariate) and treatment.

Production data was analyzed using the univariate ANOVA procedure of SPSS. Effects included in analysis of the lactation data included age, previous production, DIM, and treatment with the individual cow as the random effect, treatment group, and age as the fixed effects, and DIM and its polynomials (DIM, DIM ${ }^{2}$ ) as covariates. Repeated measures were run by nesting the individual cow-age group interaction in treatment group.

Dichotomous outcomes (in calf rates, anestrus, and Cue-mate usage) were analyzed using $\chi^{2}$. The planned start of mating to conception interval was analyzed using Kaplan Meier survival curves. Kaplan Meier curves were produced for each postulated risk factor (treatment group, age, anestrus, and calving to planned start of mating interval). The calving to planned start of mating interval was dichotomized to $\leq 42$ or $>42 \mathrm{~d}$. Culled cows were treated as censored on the day the cow left the herd; nonpregnant cows were censored on the last day of 122-d observation period. A log-rank test for difference among groups was performed. A pooled log-rank test across strata was used when single strata were examined and specific log rank statistics were used when multiple strata were examined. Effects with a $P<0.20$ were included in the final Cox model.

Significant treatment effects were noted at $P \leq 0.05$, and trends were noted at $P>0.05$ and $\leq 0.10$.

\section{RESULTS AND DISCUSSION}

\section{Liver and Blood Profiles}

There was no effect $(P>0.10)$ of $\mathrm{Cr}$ supplementation on $\mathrm{Zn}, \mathrm{Mn}, \mathrm{Cu}$, and vitamin $\mathrm{B}_{12}$ content of liver (Table 2). Cows had adequate $\mathrm{Mn}, \mathrm{Cu}$, and vitamin $\mathrm{B}_{12}$ status at 1 wk precalving and 1 mo postcalving (Puls, 1994). Zinc status of treatment and control cows was adequate at $1 \mathrm{wk}$ precalving and marginal to adequate at $1 \mathrm{mo}$ postcalving (Puls, 1994). The reduction in $\mathrm{Zn}$ status in early lactation is reflective of a lower $\mathrm{Zn}$ content in spring pasture than the turnips fed in late lactation 
Table 2. Effect of supplementing dairy cattle with $6.25 \mathrm{mg}$ of chromium ${ }^{1}$ from 6 wk prepartum to 21 wk postpartum on zinc, manganese, copper, and vitamin $\mathrm{B}_{12}$ content of liver.

\begin{tabular}{lccc}
\hline $\begin{array}{l}\text { Liver constituent, } \\
\text { mg/kg of DM }\end{array}$ & Control & Chromium & SEM \\
\hline One week precalving & & & \\
Zn & 111.3 & 102.7 & 2.0 \\
$\mathrm{Mn}$ & 9.3 & 9.3 & 0.3 \\
$\mathrm{Cu}$ & 175 & 168 & 17 \\
Vitamin $\mathrm{B}_{12}$ & 3.3 & 3.4 & 0.1 \\
One month postcalving & & & \\
$\mathrm{Zn}$ & 80.7 & 79.7 & 3.3 \\
$\mathrm{Mn}$ & 12.3 & 12.3 & 0.3 \\
$\mathrm{Cu}$ & 155 & 154 & 16 \\
Vitamin $\mathrm{B}_{12}$ & 4.3 & 4.1 & 0.1 \\
\hline
\end{tabular}

${ }^{1}$ MiCroPlex chromium-L-methionine.

(Table 1) and lactation creating a higher $\mathrm{Zn}$ requirement than pregnancy (NRC, 2001).

Due to more than $60 \%$ of the serum samples having insulin concentrations below the detection limit of 1 $\mathrm{pmol} / \mathrm{L}$, serum insulin values are not reported. Lategestation and early-lactation cattle fed preserved forages and grain typically have serum insulin levels that range from 14 to over $100 \mathrm{pmol} / \mathrm{L}$ (Kaneko et al., 1997; Hayirli et al., 2001; Holtenius et al., 2003). Serum insulin levels tend to decline from late gestation into lactation (Hayirli et al., 2001; Holtenius et al., 2003). Low serum insulin concentrations in this study may be due to analytical technique, sample handling and processing, or cattle consuming diets low in NFC. New Zealand dairy cattle typically consume diets that contain approximately $20 \%$ nonstructural carbohydrates (Kolver and de Veth, 2002), and serum insulin concentrations are commonly less than $1 \mathrm{pmol} / \mathrm{L}$ (personal communication, Roger Ellison, Alpha Scientific, Hamilton, New Zealand).

There was no effect of treatment $(P>0.10)$ on serum BHBA and plasma glucose concentrations (Table 3 ). Chromium supplementation reduced $(P \leq 0.05)$ serum NEFA concentrations by $10.6 \%$ (Table 3 ). Reduced NEFA concentration was previously observed in re-

Table 3. Effect of supplementing dairy cattle with $6.25 \mathrm{mg}$ of chromium ${ }^{1}$ from 6 wk prepartum to 21 wk postpartum on blood metabolite concentration.

\begin{tabular}{llll}
\hline Item, mmol/L & Control & Chromium & SEM \\
\hline $\begin{array}{llll}\text { Plasma } \\
\quad \text { Glucose }\end{array}$ & 2.89 & 3.01 & 0.04 \\
$\begin{array}{l}\text { Serum } \\
\quad \text {-hydroxybutyrate }\end{array}$ & 0.72 & 0.67 & 0.02 \\
Nonesterified fatty acids $^{\mathrm{a}}$ & $0.68^{\mathrm{b}}$ & $0.50^{\mathrm{c}}$ & 0.05 \\
\hline
\end{tabular}

${ }^{\text {a Time }} \times$ treatment interaction, $P \leq 0.05$.

${ }^{b, c} \mathrm{LS}$ means lacking a common superscript letter differ $(P=0.05)$.

${ }^{1}$ MiCroPlex chromium-L-methionine.
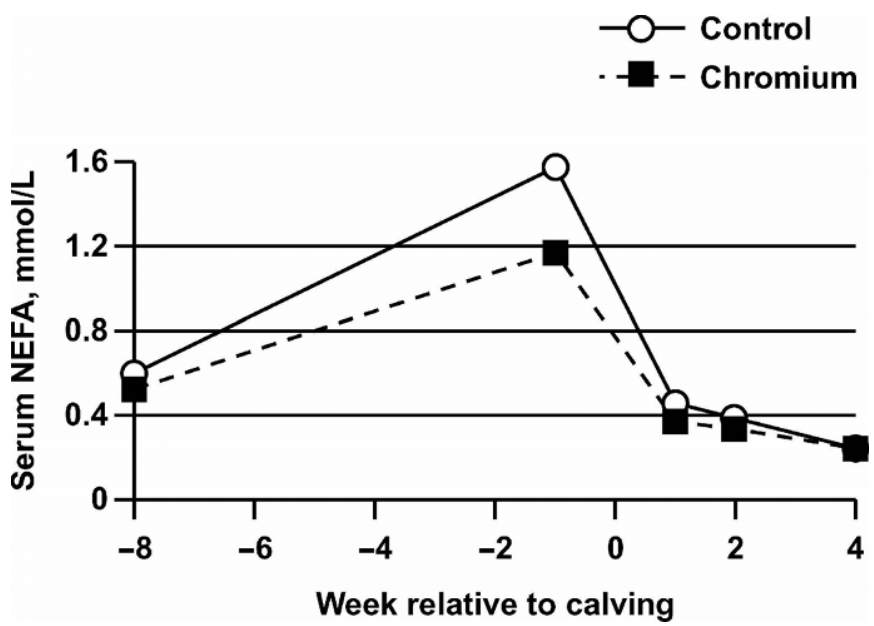

Figure 1. Effect of supplementing dairy cattle with $6.25 \mathrm{mg}$ of $\mathrm{Cr}$, from $\mathrm{Cr}$ Met, from $6 \mathrm{wk}$ prepartum to $21 \mathrm{wk}$ postpartum on serum NEFA concentration. Time $\times$ treatment interaction, $P \leq 0.05$. $\mathrm{SEM}=0.05$.

sponse to Cr supplementation (Yang et al., 1996; DePew et al., 1998; Hayirli et al., 2001). Reduced blood NEFA concentration in response to $\mathrm{Cr}$ supplementation may be partially attributed to reduced blood cortisol levels (Chang and Mowat, 1992; Moonsie-Shageer and Mowat, 1993; Almeida and Barajas, 2001), as cortisol acts antagonistically to insulin, reducing glucose uptake by peripheral tissue (Burton, 1995). Reduced glucose uptake by peripheral tissue results in increased mobilization of body tissue as the animal attempts to fulfill its energy needs (Munck et al., 1984).

The effect of treatment on serum NEFA was not consistent across time (time $\times$ treatment interaction, $P \leq$ 0.05; Figure 1). Chromium supplementation reduced serum NEFA concentrations at wk 1 prepartum, but not at wk 1, 2, and 4 postpartum. Similarly, Hayirli et al. (2001) observed that $\mathrm{Cr}$ supplementation reduced plasma NEFA concentration at d 10 prepartum, but not at $d 21$ or 28 postpartum.

\section{Lactation Data}

There was no effect of treatment $(P>0.10)$ on yield of milk, ECM, 3.5\% fat-corrected milk, milk components, and milk composition (Table 4). In contrast, feeding 250 to $800 \mathrm{ppb}$ of supplemental $\mathrm{Cr}$ from organic sources increased milk production between 2.3 and 14.9\% (Yang et al., 1996; Hayirli et al., 2001; Smith, 2004). It should be noted that Hayirli et al. (2001) observed that the milk-yield response to supplemental $\mathrm{Cr}$ was quadratic. Cows fed $0.06 \mathrm{mg}$ of $\mathrm{Cr} / \mathrm{kg} \mathrm{BW}^{0.75}$ (447 ppb for a 635-kg cow consuming $17 \mathrm{~kg}$ of $\mathrm{DM}$ ) produced $5.0 \mathrm{~kg}$ more milk than control cows, whereas cows fed 
Table 4. Effect of supplementing dairy cattle with $6.25 \mathrm{mg}$ of chromium ${ }^{1}$ from 6 wk prepartum to 21 wk postpartum on lactation performance.

\begin{tabular}{llll}
\hline Measurement & Control & Chromium & SEM \\
\hline Milk, kg/d & 26.7 & 26.0 & 0.4 \\
Energy-corrected milk, $^{2}$ kg/d & 32.4 & 31.4 & 0.5 \\
$3.5 \%$ FCM, kg/d & 29.2 & 28.2 & 0.4 \\
Milk fat, kg/d & 1.09 & 1.04 & 0.18 \\
Milk protein, kg/d & 0.94 & 0.92 & 0.18 \\
Milk solids, ${ }^{3} \mathrm{~kg} / \mathrm{d}$ & 2.03 & 1.96 & 0.03 \\
Milk fat, \% & 5.37 & 5.31 & 0.25 \\
Milk protein, \% & 4.63 & 4.69 & 0.25 \\
\hline
\end{tabular}

${ }^{1}$ MiCroPlex chromium-L-methionine.

${ }^{2}$ Energy-corrected milk $=3.5 \%$ fat and $3.2 \%$ protein.

${ }^{3}$ Solids $=$ fat + protein .

$0.12 \mathrm{mg}$ of $\mathrm{Cr} / \mathrm{kg} \mathrm{BW} \mathrm{BW}^{0.75}$ (894 ppb for a $635-\mathrm{kg}$ cow consuming $17 \mathrm{~kg}$ of DM) actually produced $1.7 \mathrm{~kg} / \mathrm{d}$ less milk than control cows. These studies indicate that oversupplementing with $\mathrm{Cr}$ can have negative effects on animal performance. In this study, average BW of cows was $514 \mathrm{~kg}$. Supplementing cows with $6.25 \mathrm{mg} / \mathrm{d}$ of $\mathrm{Cr}$ from $\mathrm{Cr}$ Met equated to $0.058 \mathrm{mg}$ of $\mathrm{Cr} / \mathrm{kg} \mathrm{BW} \mathrm{BW}^{0.75}$.

In studies where increases in milk production have been observed, increases in postpartum DMI have also been observed (Hayirli et al., 2001; Smith, 2004). It would seem logical that DMI would increase when milk production increases, especially considering body tissue mobilization, as indicated by a reduction in blood NEFA, is reduced with $\mathrm{Cr}$ supplementation. Reduced body tissue mobilization would provide less energy to sustain milk production (NRC, 2001).

Dry matter intake was not measured in this study due to the difficulty in determining intake of cattle while grazing. Failure of $\mathrm{Cr}$ to elicit a production response in this trial may have resulted from restricted energy intake. This herd was in the top 5\% of herds in New Zealand for production (more than $450 \mathrm{~kg}$ of milk solids produced per cow annually) and received daily only 0.5 to $1 \mathrm{~kg}$ of straw and $4 \mathrm{~kg}$ of wheat silage in addition to ad libitum pasture. In addition, the ability to increase pasture intake was limited during the summer months of the trial period as rainfall was below average, limiting pasture growth.

The only indicator of postpartum body tissue mobilization measured in this study was serum NEFA, and it was not affected by treatment in the postpartum period (Figure 1). Body condition and weight were not assessed, so it is only speculation that cows fed $\mathrm{Cr}$ lost less BW in this study and that this is coupled with the inability to increase DMI resulted in chromium supplementation failing to elicit a production response.

Hayirli et al. (2001) found that even though Cr supplementation had no effect on postpartum blood NEFA concentration, $\mathrm{Cr}$ supplementation tended to reduce
Table 5. Effect of supplementing dairy cattle with $6.25 \mathrm{mg}$ of chromium $^{1}$ from 6 wk prepartum to 21 wk postpartum on reproductive performance.

\begin{tabular}{llll}
\hline Measurement & Control & Chromium & $\chi^{2}$ \\
\hline $\begin{array}{l}\text { Anestrus cows, } \\
\text { 2 \% }\end{array}$ & $32.0^{\mathrm{a}}$ & $45.5^{\mathrm{b}}$ & 5.188 \\
$\begin{array}{l}\text { Progesterone-secreting } \\
\text { vaginal implant usage, }{ }^{3} \%\end{array}$ & 17.6 & 23.9 & \\
28-d pregnancy rate, \% & $39.2^{\mathrm{c}}$ & $50.0^{\mathrm{d}}$ & 1.627 \\
44-d pregnancy rate, \% & 54.4 & 61.2 & 1.225 \\
60-d pregnancy rate, \% & 71.2 & 73.1 & 0.121 \\
\hline
\end{tabular}

${ }^{\mathrm{a}, \mathrm{b}}$ Means lacking a common superscript letter differ $(P \leq 0.05)$

${ }^{\mathrm{c}, \mathrm{d}}$ Means lacking a common superscript letter differ $(P \leq 0.10)$.

${ }^{1} \mathrm{MiCroPlex}$ chromium-L-methionine.

${ }^{2}$ Cows visually observed by dairy personnel to be noncycling at 7 $\mathrm{d}$ before planned start of mating.

${ }^{3}$ Given to cows determined by rectal palpation to have no ovarian activity.

loss of body condition in the postpartum period. Similarly, Smith (2004) found that Cr supplementation had no effect on postpartum blood NEFA concentration, but cows supplemented with $\mathrm{Cr}$ had higher postpartum BW. Prepartum, there was no difference in BW, indicating that cows supplemented with $\mathrm{Cr}$ were mobilizing less body tissue in the postpartum period.

\section{Reproduction Data}

The dairy producer had visually observed more $(P \leq$ $0.05)$ noncycling cows in the supplemented group than in the control group (Table $5 ; 45.5$ vs. $32.0 \%$ ). Upon

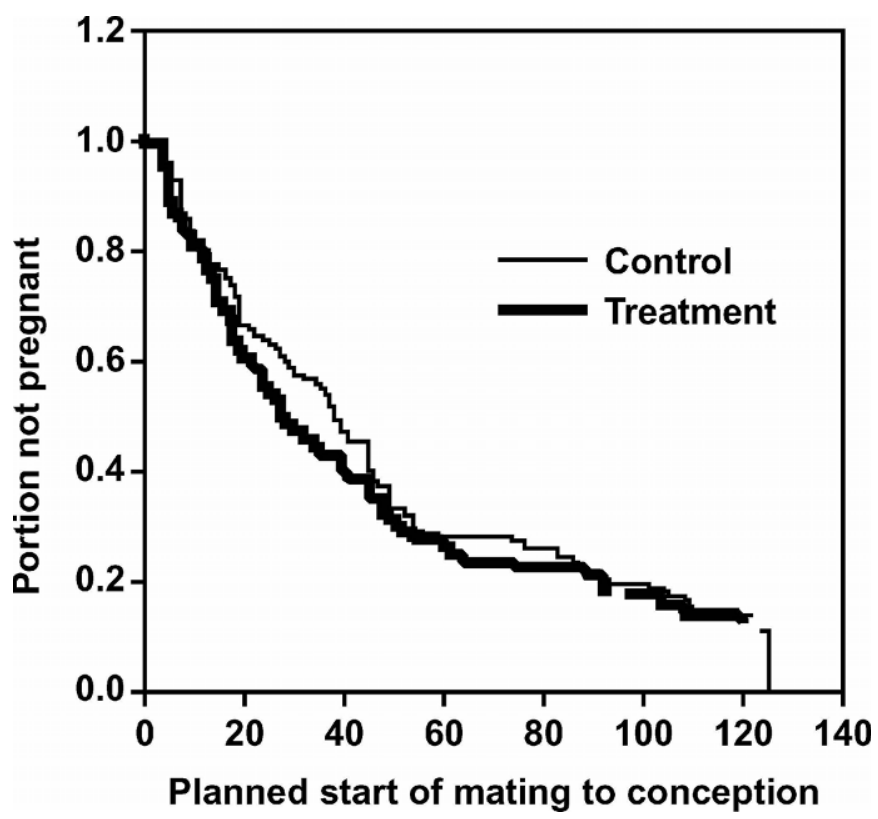

Figure 2. Effect of supplementing dairy cattle with $6.25 \mathrm{mg}$ of $\mathrm{Cr}$, from $\mathrm{Cr}$ Met, from 6 wk prepartum to 21 wk postpartum on interval from planned start of mating to conception. Kaplan Meier survival curve analysis, $P>0.10$, logistic rank test statistic 0.35 . 


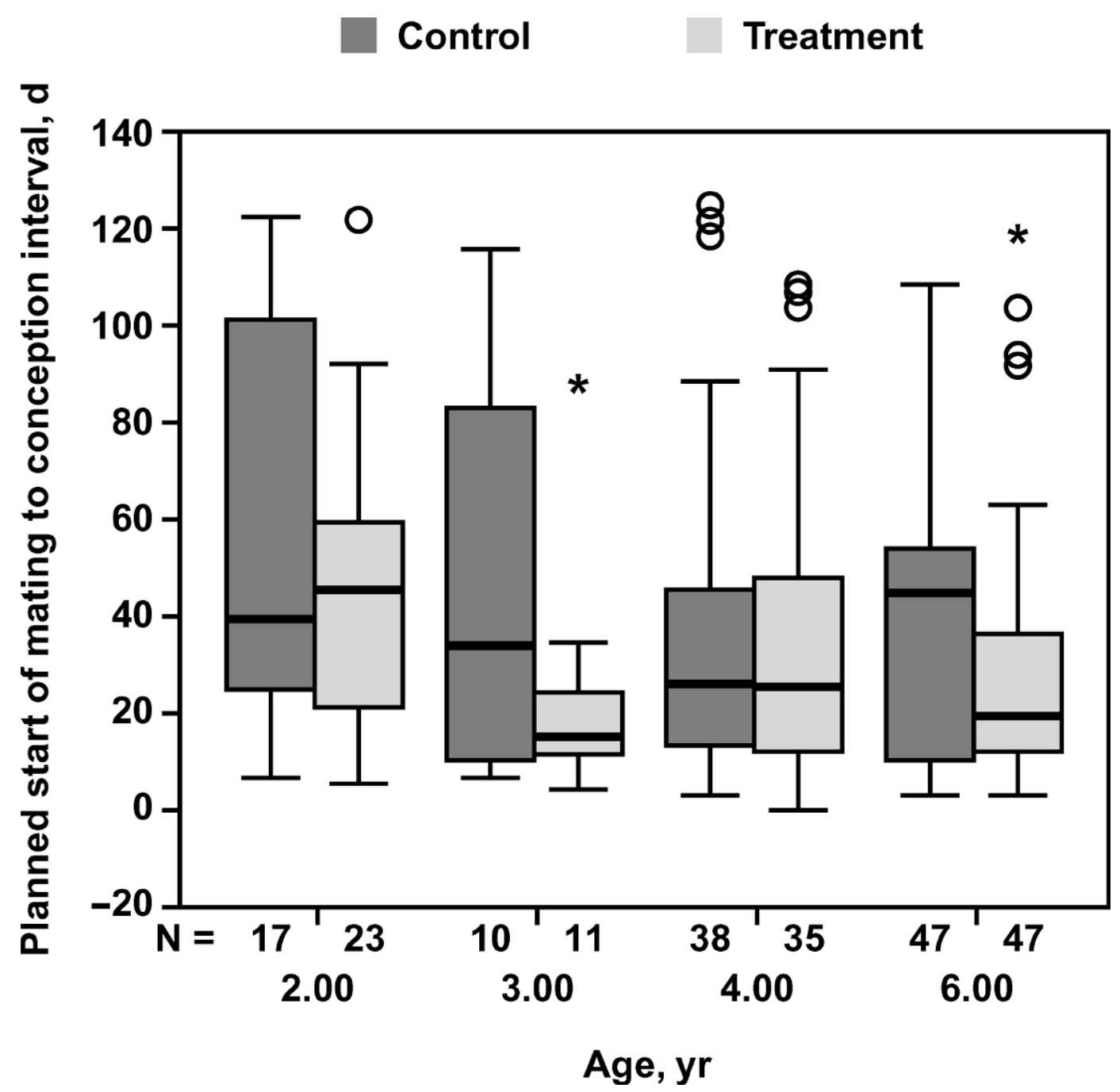

Figure 3. Boxplot analysis of the effect of age and supplementing dairy cattle with $6.25 \mathrm{mg}$ of chromium ${ }^{\mathrm{a}}$ from 6 wk prepartum to 21 wk postpartum on interval from planned start of mating to conception. The lower and upper \pm 1.5 quartile are indicated by the whiskers, the lower and upper ends of the boxes indicate the 25th and 75th quartiles, and the line across the middle of the box identifies the median sample value.

rectal palpation, however, a greater proportion of $\mathrm{Cr}-$ supplemented cows that were deemed anestrus by dairy personnel had ovarian activity than control cows, thus there was no effect $(P>0.10)$ of treatment on usage of progesterone-releasing vaginal implants.

Chromium supplemented cows tended to have a higher $(P \leq 0.10) 28$-d pregnancy rate than control cows (Table $5 ; 50.0$ vs. $39.2 \%$ ). There was no difference in 44- and 60-d pregnancy rates, although numerically, cows supplemented with $\mathrm{Cr}$ had a greater percentage of cows pregnant in the first 44- and 60-d of the mating (Table 5; 61.2 and 73.1 vs. 54.4 and $71.2 \%$ ).

Anestrus cows and cows with a calving to planned start of mating interval $\leq 42 \mathrm{~d}$ tended to have a lower risk of conception $(P \leq 0.10)$. None of the other putative risk factors influenced planned start of mating to conception interval. Thus a Cox proportional hazards model was not justified. The median days from planned start of mating to conception were 38 and $27 \mathrm{~d}$ for control and $\mathrm{Cr}$ supplemented cows, respectively, and was not influenced $(P>0.10)$ by treatment (Figure 2). However, the variation in intervals from start of planned mating to conception tended to be less for Cr supplemented cows, in particular the 3-yr-old cows as indicated by box-plot analysis (Figure 3 ).

These results suggest that $\mathrm{Cr}$ may help mitigate the effects of anestrus on fertility of cows early in the breeding season. Another plausible explanation is that there was a greater failure rate in observing estrus in the Cr-supplemented cows, resulting in a greater portion 
of supplemented cows being incorrectly classified as anestrus.

Data showing a positive effect of $\mathrm{Cr}$ supplementation on reproduction is limited. Yang et al. (1996) found that 14 of the $17 \mathrm{Cr}$ supplemented cows conceived during or after the trial, whereas 12 of the 17 control cows conceived during the same period. Yang et al. (1996) also found that $\mathrm{Cr}$-supplemented cows averaged, numerically, 9 fewer days open than control cows.

In swine, the effect of $\mathrm{Cr}$ supplementation has been studied more extensively and a common response to $\mathrm{Cr}$ supplementation is increased litter sizes (Lindemann et al. 1995; Hagen et al., 1999). The proposed mechanism for Cr increasing litter size is increased insulin sensitivity. Insulin stimulates granulose cell proliferation (Spicer and Echternkamp, 1995) and reduces follicular atresia (Matamoros et al., 1990). In addition, insulin has been shown to increase ovulation rates in pigs (Cox et al., 1987; Flowers et al., 1989) potentially by affecting LH release from the hypothalamus or pituitary gland (Flowers et al., 1989).

Getting cows pregnant in the first $60 \mathrm{~d}$ of mating is critical due to the seasonality of the New Zealand dairy industry. Cows that conceive late are induced to calve resulting in economic loss due to reduced lactation performance and increased risk of retained placentas, milk fever, and loss of a potentially viable calf.

\section{CONCLUSIONS}

Results of this study indicate that supplementing intensively grazed cattle with $\mathrm{Cr}$ did not improve lactation performance. The exact reason for lack of response needs to be investigated further. Chromium supplementation showed a trend toward improved reproduction as indicated by increased percentage of cows pregnant in the first $28 \mathrm{~d}$ of the mating season. Supplementing intensively grazed cattle with $\mathrm{Cr}$ reduced blood NEFA concentrations precalving but not postcalving.

\section{ACKNOWLEDGMENTS}

Appreciation is extended to John and Teresa van Hout and staff for their dedication in carrying out the trial protocol.

\section{REFERENCES}

Almeida, L., and R. Barajas. 2001. Effect of Cr-methionine level supplementation on immune response of bull claves recently arrived to feedlot. J. Anim. Sci. 79(Suppl. 1):390. (Abstr.)

Almeida, L., and R. Barajas. 2002. Effect of Cr methionine and zinc methionine supplementation on blood concentrations of immunoglobulin $\mathrm{G}$ and $\mathrm{M}$ and inflammatory response to a phytohemagglutinin in stressed feedlot calves. J. Anim. Sci. 80(Suppl. 1):363. (Abstr.)
Anderson, R. A. 1987. Chromium in tissues and fluids. Page 225 in Trace Elements in Human and Animal Nutrition. 5th ed. Academic Press, San Diego, CA.

Anderson, R. A., N. A. Bryden, M. M. Polansky, and P. B. Moser. 1988. Exercise effects on $\mathrm{Cr}$ excretion of trained and untrained men consuming a constant diet. J. Appl. Physiol. 64:249-252.

Borel, J. S., T. C. Majerus, M. M. Polansky, P. B. Moser, and R. A. Anderson. 1984. Chromium intake and urinary chromium excretion of trauma patients. Biol. Trace Elem. Res. 6:317.

Burton, J. L. 1995. Supplemental chromium: Its benefits to the bovine immune system. Anim. Feed Sci. Technol. 53:117-133.

Burton, J. L., B. A. Mallard, and D. N. Mowat. 1993. Effects of supplemental chromium on immune responses of periparturient and early lactation dairy cows. J. Anim. Sci. 71:1532-1539.

Burton, J. L., B. A. Mallard, and D. N. Mowat. 1994. Effects of supplemental chromium on antibody responses of newly weaned feedlot calves to immunization with infectious bovine rhinotracheitis and parainfluenza 3 virus. Can. J. Vet. Res. 58:148-151.

Burton, J. L., B. J. Nonnecke, P. L. Dubeski, T. H. Elsasser, and B. A. Mallard. 1996. Effects of supplemental chromium on production of cytokines by mitogen-stimulated bovine peripheral blood mononuclear cells. J. Dairy Sci. 79:2237-2246.

Cameron, R. E. B., P. B. Dyk, T. H. Herdt, J. B. Kaneene, R. Miller, H. F. Bucholtz, J. S. Liesman, M. J. Vandehaar, and R. S. Emery. 1998. Dry cow diet, management, and energy balance as risk factors for displaced abomasums in high producing dairy herds. J. Dairy Sci. 81:132-139.

Campbell, M. H., J. K. Miller, and F. N. Schrick. 1999. Effect of additional cobalt, copper, manganese, and zinc on reproduction and milk yield of lactating dairy cows receiving bovine somatotropin. J. Dairy Sci. 82:1019-1025.

Chang, X., and D. N. Mowat. 1992. Supplemental chromium for stressed and growing feeder calves. J. Anim. Sci. 70:559-565.

Cox, N. M., M. J. Stuart, T. G. Athen, W. A. Bennett, and H. W. Miller. 1987. Enhancement of ovulation rate in gilts by increasing dietary energy and administering insulin during follicular growth. J. Anim. Sci. 64:507-516.

DePew, C. L., L. D. Bunting, J. M. Fernandez, D. L. Thompson, Jr., and R. W. Adkinson. 1998. Performance and metabolic responses of young dairy calves supplemented with chromium tripicolinate. J. Dairy Sci. 81:2916-2923.

Drackley, J. K. 1999. Biology of dairy cows during the transition period: The final frontier? J. Dairy Sci. 82:2259-2273.

Flowers, B., M. J. Martin, T. C. Cantley, and B. N. Day. 1989. Endocrine changes associated with a dietary-induced increase in ovulation rate (flushing) in gilts. J. Anim. Sci. 67:771-778.

Gunnink, J. W. 1984. Pre-partum leucocytic activity and retained placenta. Vet. Q. 6:52-54.

Hagen, C. D., M. D. Lindemann, and K. W. Purser. 1999. Dietary chromium tripicolinate increases sow productivity under commercial conditions. J. Anim. Sci. 77(Suppl. 1):67. (Abstr.)

Hayirli, A., D. R. Bremmer, S. J. Bertics, M. T. Socha, and R. R. Grummer. 2001. Effect of chromium supplementation on production and metabolic parameters in periparturient dairy cows. J. Dairy Sci. 84:1218-1230.

Holtenius, K., S. Agenas, C. Delavaud, and Y. Chilliard. 2003. Effects of feeding intensity during the dry period. 2. Metabolic and hormonal responses. J. Dairy Sci. 86:883-891.

Kaneko, J. J., J. W. Harvey, and M. L. Bruss, ed. 1997. Clinical Biochemistry of Domestic Animals. 5th ed. Academic Press, San Diego, CA.

Kimura, K., J. P. Goff, M. E. Kehrli, Jr., and T. A. Reinhardt. 2002. Decreased neutrophil function as a cause of retained placenta in dairy cattle. J. Dairy Sci. 85:544-550.

Kolver, E. S., and M. J. de Veth. 2002. Prediction of ruminal $\mathrm{pH}$ from pasture-based diets. J. Dairy Sci. 85:1255-1266.

Lindemann, M. D., C. M. Wood, A. F. Harper, E. T. Kornegay, and R. A. Anderson. 1995. Dietary chromium picolinate additions improve gain:feed and carcass characteristics in growing-finishing pigs and increase litter size in reproducing sows. J. Anim. Sci. 73:457-465. 
Matamoros, I. A., N. M. Cox, and A. B. Moore. 1990. Exogenous insulin and additional energy affect follicular distribution, follicular steroid concentrations, and granulosa cell human chorionic gonadotropin binding in swine. Biol. Reprod. 43:1-7.

McDougall, S. 2001. Effect of periparturient diseases and conditions on the reproduction performance of New Zealand dairy cows. N.Z. Vet. J. 49:60-67.

Mertz, W. 1993. Chromium in human nutrition: A review. J. Nutr. 123:626.

Moonsie-Shageer, S., and D. N. Mowat. 1993. Effect of level of supplemental chromium on performance, serum constituents, and immune status of stressed feeder calves. J. Anim. Sci. 71:232-238.

Munck, A., P. Guyre, and N. Holbrook. 1984. Physiological functions of glucocorticoids in stress and their relation to pharmacological actions. Endocrinol. Rev. 5:25-44.
National Research Council. 2001. Nutrient Requirements of Dairy Cattle. 7th rev. ed. Natl. Acad. Sci., Washington, DC.

Puls, R. 1994. Mineral Levels in Animal Health. Sherpa International, Clearbrook, British Columbia.

Smith, K. L. 2004. Effects of prepartum carbohydrate source and chromium supplementation in dairy cows during the periparturient period. M.S. Thesis, Cornell Univ., Ithaca, NY.

Spicer, L. J., and S. E. Echternkamp. 1995. The ovarian and insulinlike growth factor system with an emphasis on domestic animals. Domest. Anim. Endocrinol. 12:223-245.

Westwood, C. T., I. J. Lean, and J. K. Gavin. 2002. Factors influencing fertility of Holstein dairy cows: A multivariate description. J. Dairy Sci. 85:3225-3237.

Yang, W. Z., D. N. Mowat, A. Subiyatno, and R. M. Liptrap. 1996. Effects of chromium supplementation on early lactation performance of Holstein cows. Can. J. Anim. Sci. 76:221-230. 